\title{
Making Simple Repairs: Door and Lock Problems ${ }^{1}$
}

Mary N. Harrison ${ }^{2}$

Getting stuck outside of your apartment or in a room can be frustrating. Prevent this from happening by following some simple rules and doing some minor repairs.

\section{Prevention}

- Give your keys a "home." Always put them in the same place and check for them before you lock your door! Landlords may charge you if you lose your keys. Many landlords do not consider it an emergency if you get locked out. NEVER PICK A LOCK!

- Close doors gently. Slamming them loosens hardware and molding. Slamming a door against a wall can damage the wall. The doorknob can knock a hole in the wall or the doorstop can damage the door. If such damage occurs, it will affect your security deposit.

\section{Problems You Can Fix}
A. Squeaky Doors
B. Loose Screws

\author{
C. Sticking Or Dragging Door. \\ D. Squeaky Door Locks/Tight Locks \\ E. Loose Or Rattling Doorknobs
}

\section{A. Squeaky Door}

Supplies Needed:

- Oil

- Hammer

- Nail

How To Fix:

1. You can usually stop a door squeak by putting a few drops of oil at the top of each hinge. Move the door back and forth to work the oil into the hinge. If the squeaking does not stop, raise the pin and add more oil.

2. To raise the pin, place a nail against the bottom of the pin. Hammer the nail to push the pin up.

1. This document is FCS5234-06 one of a series of the Department of Family, Youth and Community Sciences, Florida Cooperative Extension Service, Institute of Food and Agriculture Sciences, University of Florida. Publication: May 2002. Revised: December 2005. Please visit the EDIS Web site at http://edis.ifas.ufl.edu.

2. Mary N. Harrison, professor, Department of Family, Youth and Community Sciences, Cooperative Extension Service, Institute of Food and Agricultural Sciences, University of Florida, Gainesville, 32611.

The Institute of Food and Agricultural Sciences (IFAS) is an Equal Opportunity Institution authorized to provide research, educational information and other services only to individuals and institutions that function with non-discrimination with respect to race, creed, color, religion, age, disability, sex, sexual orientation, marital status, national origin, political opinions or affiliations. U.S. Department of Agriculture, Cooperative Extension Service, University of Florida, IFAS, Florida A. \& M. University Cooperative Extension Program, and Boards of County Commissioners Cooperating. Larry Arrington, Dean 
3. Another way to remove the pin is to place a screwdriver under the head of the pin and tap the screwdriver with a hammer.

\section{B. Loose Screws}

Supplies Needed:

- Screwdriver

- Screws

How To Fix:

Tighten screws in the hinges. If screws are not holding, replace them, one at a time, with a longer screw. Or insert a wooden matchstick in the hole and put the old screw back in place.

\section{Sticking or Dragging Door}

Supplies Needed:

- Sandpaper

How To Fix:

Look for a shiny spot on the door where it sticks. Open and close the door slowly to find the spot. Sand down the shiny spot. Do not sand too much, or the door will not fit as tight as it should.

If the door or frame is badly out of shape, contact your landlord.

\section{Squeaky Door Locks or Tight Locks}

Supplies Needed:

- Graphite pencil (from the hardware store)

How To Fix:

Noisy or squeaky locks should be lubricated with graphite. If the lock is tight or will not turn, you may also lubricate it with graphite.

\section{E. Loose or Rattling Doorknobs}

Supplies Needed:

- Screwdriver
- Putty

How To Fix:

- Check to see if the setscrew is loose. If so, tighten the screw with a screwdriver. If it is not loose then loosen the setscrew on the doorknob.

- Remove the knob. Put a small piece of putty or modeling clay in the knob.

- Put the knob back on. Push it on as far as possible. Tighten the screw. 